\title{
MANAGEMENT \\ ON THE NEOEVOLUTIONARY FOUNDATIONS
}

\section{Introduction}

The Darwinian theory of evolution is a fundamental, consolidated philosophy and methodology of biological sciences that deserves to be called a paradigm. However, early attempts to use the paradigm in social sciences are rather unsuccessful. In the 19th century, the "survival of the fittest" became a synonym for Herbert Spencer's social evolutionism, which the next generations of intellectuals associate with discrimination, or even with the ideology of Nazizm ${ }^{1}$. In the 20 th century, social interpretations of Wilson's sociobiology, which reduced the humanities and social sciences to biological and genetic foundations, were received with indignation. Similarly, the assumptions of Richard Dawkins's memetics were met with quite significant scepticism $^{2}$. It seems, however, that in the face of an extremely dynamic development of empirical research based on the evolutionary paradigm, which allows the explanation of numerous behaviours of organisms including human beings, Darwinism deserves a second chance to gain significance in social sciences. Many contemporary scientific disciplines offer this new approach. These disciplines include: evolutionary psychology, sociobiology, cognitive science, primatology, artificial intelligence or neuroscience. By combining experiences in studying human behaviour taken from social and humanistic disciplines with the paradigm of evolutionism and contemporary methods of brain cognition, research in social sciences may become much

\footnotetext{
* B. z. Lukasz Sułkowski, Jagiellonian University, Academy of Management SWSPiZ, Lodz.

1 H. Spencer, Principles of Biology, 1864, vol. 1, p. 444, after: M.E. Stucke, Better Competition Advocacy. http://works.bepress.com/cgi/viewcontent.cgi?article=1000\&context=maurice_stucke.

2 S.J. Gould, R. Lewontin, 1979, The spandrels of San Marco and the Panglossion paradigm: a critique of the adaptationist programme. Proc $R$ Soc Lond B 205: 581-598.
} 
more dynamic ${ }^{3}$. Transferring evolutionary paradigm to social sciences is an essential cognitive condition that allows developing this interdisciplinary alliance. In psychology we observe fast development of this approach, called evolutionary psychology, which at the same time is a response to critical opinions on orthodox sociobiology ${ }^{4}$. Controversies related to applying evolutionism in cultural sociology and anthropology are considerably larger. From the perspective of management sciences it seems that the evolutionary trend studies are very distant from the problems of an organisation, after a more profound analysis it becomes clear, however, that adopting evolutionary explanations influences the functioning of all sciences studying human behaviour (behavioural sciences).

The purpose of the article is to outline the perspective of the influence of contemporary evolution concept on social sciences, management in particular. It covers searching for sources of the processes of organisation and management in the biological and social specificity of the homo sapiens species. Darwinian inspirations allow better understanding of people's actions in organisations ${ }^{5}$.

\section{Neoevolutionism vs. human behaviour}

The theory of evolution related to natural selection and sexual selection was developed by Carl Darwin. It points at the fundamental mechanism of species' adaptation to environmental conditions by means of an accidental, accumulated change. The theory of genetic endowment was created later and it made it possible to coherently explain the mechanism of reproduction and genetic change (mutation) ${ }^{6}$. In 1964, William D. Hamilton described the evolution theory from the perspective of spreading genes, pointing not only to the reproduction of genes by having offspring, but also to the bonds between relatives ${ }^{7}$. It allowed for the explanation of kin altruism, which was common in nature. In the seventies of the previous century, Robert Trivers proposed evolutionary theories explaining reciprocal non-kin altruism, the concept of parental investment and conflict between parents and children ${ }^{8}$. In

3 C. Elworthy, Homo Biologicus. An Evolutionary Model for the Human Sciences, Internet, 1993, downloaded in 2007.

4 J. Tooby, L. Cosmides, Toward Mapping the Evolved Functional Organization of Mind and Brain, w: The New Cognitive Neuroscience, red. M. Gazzaniga, MIT Press, Cambridge 2000, pp. 1167-1178.

5 See: Ł. Sułkowski, W cieniu Darwina - inspiracje ewolucjonistyczne w zarzadzaniu, „Współczesne Zarządzanie" 2008, no. 4.

6 W. Bateson, Mendel's Principles of Heredity, a Defense, First Edition, Cambridge University Press, London 1902. On-line Facsimile Edition: Electronic Scholarly Publishing, prepared by Robert Robbins.

7 W.D. Hamilton, The Genetical Evolution of Socila Behaviour, "Journal of Theoretical Biology” 1964, no. 7, pp. 1-52.

8 R.L. Trivers, The Evolution of Reciprocal Altruism, „Quarterly Review of Biology” 1971, no. 46, pp. 35-57. 
1975, Edward O. Wilson published a book entitled Sociobiology. The New Synthesis, which described the condition of contemporary evolutionism, that allowed correct interpretation and forecast of behaviours in biological world 9 . The last chapter of the work, describing the application of the concept in human behaviours, however, raised huge controversy. First and foremost, it included hypotheses, and not the results of empirical research, which triggered attacks not only from ideological positions, but also from the methodological ones. The concepts of explaining human behaviours in the evolutionary perspective were taken up by evolutionary psychology and owing to intensive research carried out through the last three decades, it was possible to create a coherent evolutionary theory of human behaviour based on the evolutionary paradigm ${ }^{10}$.

The assumptions of neoevolutionary synthesis combine the concept of natural and sexual selection with the idea of genes' replication ${ }^{11}$ :

1. Natural selection of behaviours assuming that in a long-term perspective of the existence of homo sapiens, structures and behaviours favouring individual survival of the representatives of species lived on, while impractical structures and behaviours gradually disappeared (excluding the behaviours granting reproductive advantage).

2. Sexual selection of behaviours assuming that in a long-term perspective of the existence of homo sapiens, structures and behaviours increasing the chances of individual reproduction survived, even if they were impractical from the point of view of the survival of individuals ${ }^{12}$.

3. Module-based concept of the mind assuming that in the course of evolution, specific "software" serving the solution of many problems related to survival and reproduction (adaptation) such as avoiding predators, selection of food, establishing social contacts and friendships, helping the kin, caring about children, communication with others, pursuit of domination, identifying social frauds, sexual behaviours etc. ${ }^{13}$, has developed in the brain of a human being, and earlier in the brains of other species.

4. Theory of genes' egoism, which states that genetic reproduction and spreading one's own genes, which may be achieved by having offspring and by supporting

9 E.O. Wilson, Socjobiologia, Zysk i S-ka, Poznań 2001.

10 J. Tooby, L. Cosmides, Toward Mapping the Evolved Functional Organization of Mind and Brain, in: The New Cognitive Neuroscience, red. M.S. Gazzaniga, MIT Press, Cambridge 2000, pp. 1167-1178.

11 L. Barrett, R. Dunbar, J. Lycett, Human Evolutionary Psychology, Palgrave Macmillan, New York 2002, pp. 22-44; D.M. Buss, Evolutionary Psychology. The New Science of the Mind, Pearson, Boston 2008, pp. 36-69.

12 G. Miller, The mating mind: how sexual choice shaped the evolution of human nature, Heineman, London 2000 .

13 J.A. Fodor, The Modularity of Mind:An Essay in Faculty Psychology, The MIT Press, 1983; J. Barkow, L. Cosmides, J. Tooby, The adapted mind: Evolutionary psychology and the generation of culture, Oxford University Press, Oxford 1992. 
the reproduction of relatives, i.e. those based on a common genetic element ${ }^{14}$, remains a fundamental motive for the actions of individuals.

5. Kin-related mechanisms of development resulting directly from the assumption of genes' egoism and explaining the issues of taking care of children, parental investment and kin altruism.

6. Man's social nature, which is inscribed in evolutionary mechanisms, as most problems with adaptation are resolved inside a group and by a social group. Ensuring food supply, sexual selection, caring about children, communication and domination - all these elements are social activities, which proves that a human being is naturally prepared for social life, which of course does not mean that social mechanisms develop independently on a genetic basis and do not require socialisation.

7. Assuming the existence of differences between genders, which are a natural consequence of biological and social differentiation, as well as of differences between men and women in the sphere of sexual behaviours, perceptions and emotions related to different roles they have had in gathering and hunting communities through millions of years of species development.

Contemporary neoevolutionism has become a dominating paradigm in biological sciences that leads to coherent and verifiable explanations of human behaviours. The assumptions of natural and sexual selections and the egoism of genes allow for the understanding of the specific nature of social behaviour of human beings, and they are a challenge for the humanities. Several scientific disciplines, such as evolutionary psychology, sociobiology, neuroscience and cognitive science, situated somewhere between biology and social sciences, develop on the basis of the neoevolutionary paradigm.

\section{Applying neoevolutionism to management}

Evolutionism may serve as a basis for explaining many collective behaviours of people, which are a foundation for the processes of organisation and management. Thus, it is worth looking at potential applications of this paradigm and to set out further directions for research as part of management sciences ${ }^{15}$.

Studies of the neoevolutionary trend, applied to organisational activities in the economic aspect, point to significant restrictions of the rationality of decision-making processes that result from "human nature". Man is a "vehicle of genes", he inherits

14 D.S. Wilson, E.O. Wilson, Rethinking the Theoretical Foundations of Sociobiology, "The Quarterly Review of Biology" 2007, 82 (4), pp. 327-348.

15 See Ł. Sułkowski, Paradygmat neoewolucyjny w naukach o zarzadzaniu, „Przegląd organizacji” 2009, no. 3 . 
mechanisms of environmental and genetic coupling, which serves genetic replication, which in turn means that "human nature" is not endlessly flexible and cannot perfectly observe the rules of rational development of an organisation ${ }^{16}$. Conscious and rational decision-making processes are merely the "top", youngest part of the human brain, whereas, as neurobiological research proves, decisions are made on many levels of the brain, often in the blink of an eye and on the basis of very limited information ${ }^{17}$. Evolutionary justification of these decisions was a stake related to organism survival (e.g. instant fight-or-flee responses) ${ }^{18}$. Thus, in human actions we often deal only with conscious rationalisation of behaviours that are hidden in the layers of unconsciousness and that are called intuition or subconsciousness. Man's cognitive apparatus, which has evolved in the environment full of natural threats, is not a mechanism of fully logical and rational decision-making. Perceptive and interpretational illusions and stereotypes that draw the real model of decision-making further from the ideal of rationality and logics play a significant role in the functioning of a human being.

The evolutionary paradigm starts to permeate social sciences, which is manifested in the dynamic development of evolutionary psychology and sociobiology. What are the possibilities of applying this paradigm to management sciences? They cover a broad scope of social problems based on an evolutionary foundation, such as:

1. biological roots of organising,

2. evolutionary restrictions of rationality,

3. natural sources of the structure of power,

4. competition between individuals, conflict and fight for domination,

5. leadership in an organisation,

6. learning,

7. group and organisational bonds,

8. risk taking,

9. communication,

10. sexual behaviours,

11. evolutionary conditioning of the culture of societies and organisations.

\section{Biological roots of organising}

Processes of organising are rooted in human nature. Most activities we perform have a social and organised character. Man as a social creature is shaped by bonds

16 R. Dawkins, The Selfish Gene, Oxford University Press, Oxford 1976.

17 M. Gladwell, Blink. The Power of Thinking Without Thinking, Time Warner Book Group, New York 2005.

18 See H.C. Barrett, Adaptations to Predators and Prey, w: The Handbook of Evolutionary Psychology, red. D.M. Buss, Wiley, New York 2005, pp. 200-223. 
and interactions with other people. It means that an organising function, which enables and optimises collective actions, emerges in the evolutionary process. In order for it to exist, a person must have motivation and skills that allow for group work. In collective work, they are transferred upon an individual in the process of primary socialisation by the family and a small social group. Assimilation of values, attitudes and models is carried out naturally, among others by imitation and conditioning. Solving basic life problems related to finding food (hunting or gathering), finding a shelter or taking care of children by a primitive group requires cooperation. On the basis of earlier evolutionary mechanisms of domination, cooperation and conflict, group leadership, making key decisions in terms of selecting proper solutions thus allowing for survival and reproduction, emerges. The organising function acquires greater meaning when the individual and the group deal with less routine tasks, tasks that lack ready solutions available in the set of standard cultural patterns. Creative mechanisms, whose development was an immense evolutionary cost, are activated here. Owing to flexible, non-routine organising, leadership and creativity, the social group of homo sapiens is capable of solving the most complex survival problems, even in the most difficult and unstable conditions. No wonder that it populated the entire globe so fast, e.i. in evolutionary terms.

\section{Evolutionary restrictions of rationality}

Behavioural economy is a discipline dealing with restrictions of economic actions rooted in the evolutionary nature of man $^{19}$. The research programme carried out since the 1970's until today by Amos Tverski and Daniel Kahneman, Colin Camerer, Richard Thaler, Paul Slavic, Thomas Gilovich and others concentrates on illusions and cognitive errors rooted in human nature ${ }^{20}$. It has contributed to describing several universal cognitive biases that are based on evolution. It seems that some of them play a significant role in human resources management. "Representative fallacy" indicates that in situations that require statistical estimations, people use a limited number of heuristics that lead to inability to adequately assess event probability ${ }^{21}$. "Availability fallacy" consists in assessing probability and generalisations only on the basis of examples to which there is easy and immediate access ${ }^{22}$. For instance, estimating the probability of a plane crash in relation to other accidents will be considerably

19 Advances in Behavioral Economics, red. C.F. Camerer, G. Loewenstein, M. Rabin, Princeton University Press, Princeton NJ 2001.

20 T. Gilovich, D. Griffin, D. Kahneman, Heuristics and Biases: The Psychology of Intuitive Judgment, Cambridge University Press, New York 2002.

21 A. Tversky, D. Kahneman, Availability: A Heuristics for Judging Frequency and Probability, in: Judgment Under Uncertainty: Heuristics and Biases, red. D. Kahneman, P. Slovic, A. Tversky, Cambridge University Press, New York 1982.

22 Ibid., p. 163. 
exaggerated due to the overrepresentation of information on plane crashes in massmedia ${ }^{23}$. "Hindsight bias" is a tendency to interpret the past, making unconscious, selective use of the memory and explaining past events so that they fit in the present knowledge ${ }^{24}$. "Confirmation bias" consists in searching only for the information that complies with one's beliefs and rejecting the data that could contribute to rejecting them ${ }^{25}$. "Endowment effect" indicates that the value of an object in one's possession is subjective - for the owner it is usually far higher than for a potential buyer ${ }^{26}$. Sources of the biases described above lie in the evolutionary nature of man's cognitive apparatus. Natural adjustments are related to an adequate assessment of small numbers, whereas probability is an abstract category that a human being cannot understand intuitively. Adaptation to life in a small group is also a generalisation on the basis of available examples. The tendency to confirm opinions is more difficult to interpret, it seems, however, that it is based on a mechanism of emotional support of the decisive effect. A decision made should be consequently implemented, or it ceases to be functional. Another evolutionary source of the "confirming effect" may be the strengthening of social group's identity and individuals' identification with the community, which results in the aversion towards foreigners. The "endowment effect" and aversion towards losses are probably related to restricted material resources that enable survival and reproduction in a primitive group. Evolutionary restrictions of rationality presented above will have a significant impact on management.

\section{Natural sources of the structure of power and hierarchy}

Power and social hierarchy do not occur only in the world of people; they are also present in the kingdom of animals. If by power we understand the possibility to impose one's own will upon other individuals, all primates and many other animal species have such a possibility. Hierarchy, biologically reflected in the "pecking order", is a static reflection of a recognised structure of power. Power and hierarchy play a special role among social species, as they place the leader not only in the position of a dominating entity, but also a decision-making entity, who imposes his will not upon individuals, but upon the entire social group. The consequences of such decisions are far more significant, as they concern all community members. What about

23 B. Combs, P. Slovic, Newspaper Coverage of Causes of Death, "Journalism Quarterly" 1979, no. 56, pp. $837-843$.

24 B. Frischhoff, For Those Condemned to Study Past: Heuristics and Biases In Hindsight, in: Judgment Under Uncertainty: Heuristics and Biases, red. D. Kahneman, P. Slovic, A. Tversky, Cambridge University Press, New York 1982, pp. 335-350.

25 R. Nickerson, Confirmation Bias: A Ubiquitous Phenomenon In Many Guises, „Review of General Psychology" 1998, no. 2, pp. 175-220.

26 R. Thaler, D. Kahneman, J. Knetsch, Experimental Tests of the Endowment Effect and the Coase Theorem, "Journal of Political Economy" 1990. 
the emergence of power and its legitimacy? Natural order assumes the domination of the strongest one, on the other hand, however, chimpanzees commonly establish coalitions that grant power to the most socially agile individual or even to a group. In order to carry out long-lasting organising projects, from the functional perspective it was essential not only to select the centre of power but also to ensure its stability.

\section{Competition between individuals, conflict and fight for domination}

Competition, conflict and fight are inseparable elements of exercising power. They have the most sophisticated forms among social species. Competition is related to limited access to resources and to individuals' unrestricted need to survive and to reproduce. Thus, we may observe fight and conflict both among individuals and coalitions inside a social group ${ }^{27}$. The complexity of competitive processes and conflicts forces one to make an effort to perform an analysis on many levels related to the issues of organising and of social games. Thus, competition is a mechanism of perfecting individual and collective actions that, in order to win in a social game, encourages to use conflict, fight and even cooperation.

\section{Leadership in an organisation}

Leadership, or the emergence of an individual who makes decisions and who imposes it on a group, is also not an exclusive feature of the homo sapiens species. It is a functional solution allowing an efficient use of the organising function. However, developing the criteria of leadership emergence and maintenance, usually based on authority, is essential. In the case of people, authority, being a measure of social respect and of group members' readiness to succumb to the will of an individual, is not a measure based only on physical strength. Although domination in the physical sense might have existed in the species' past, and although unconsciously and presently it may be a condition favouring authority, the ability to cooperate with a social group based on communication and the impact of a social model (an ideal leader, image, reputation, respect) remain more important. Evolutionary study of leadership and power are still at a preliminary stage and they mostly cover seeking mind modules that interfere with these social processes. Summing up, the features of leadership rooted in the past of the species include:

- Leadership lies in the biological nature of man, who is a social creature endowed with the most developed cognitive apparatus leading to unavoidable development

27 A. Campbell, A Few Good Men: Evolutionary Psychology and Female Adolescent Aggression, in: The Functional Mind. Readings in Evolutionary Psychology, red. D.T. Kenrick, C.L. Luce, Pearson, Boston 2004. 
of the complexity of groups and to the emergence of problems of establishing comprehensive structures of power and multi-level hierarchies.

- Leadership is beneficial both to group members, as it ensures social order and favours the coordination of team activities, and to the leader, providing him with material benefits, reproductive advantage and symbolic gratification.

- Leadership is like a social game, which involves tension between: leader's pursuit of autocracy and group's pursuit of participation, individual's and community's interest (sacrificing an individual), as well as between rivalry and cooperation of group members.

- Leadership has become one of key social mechanisms that make it possible to create big and complex social groups such as societies and states.

- The leader becomes a source of identification to its advocates. He is a symbol of the group, unifies it and builds group identity, clearly selecting group members from the environment.

\section{Learning and creativity in a social group}

From the point of view of management sciences, processes of learning and getting to know reality are crucial. They are related to the development of a cognitive model which allows solving problems. As a relatively advanced study of evolutionary psychology on the processes of learning proves, as a species we possess a cognitive apparatus that has evolved to solve concrete, open problems related to survival and reproduction, while theoretical mind is merely a side effect of functioning in an unstable environment that requires creativity. This turbulent environment is mostly one's own social group, which grants people immense possibilities, but at the same time it forces them to cope with changeability, unpredictability and creativity. Among numerous interesting studies of man's cognitive processes determined by evolution one can for instance point to the syndromes of fast learning on the basis of aversive and biological foundations of conditioning and the specific character of learning in the processes of primary and secondary socialisation ${ }^{28}$.

\section{Group and organisational bonds: Kin and non-kin altruism}

Explaining the establishment of group bonds, mostly kin bonds, has become one of the first problems of contemporary applications of evolutionism in social sciences. According to Hamilton's, Williams's and Trivers's studies, genetic community is the cause of developing kin bonds. It also means that the strength of a kin bond is directly

28 M.E.P. Seligman, J.L. Hager, Biological Boundaries of Learning: The Sauce-Bernaise Syndrome, in: The Functional Mind. Readings in Evolutionary Psychology, red. D.T. Kenrick, C.L. Luce, Pearson, Boston 2004. 
proportional to genetic proximity. In social sciences, it is obviously a valuable explanation not only from the point of view of family-oriented sociology, but also of the issue of nepotism in society. The interpretation of non-kin altruism is more problematic. Why are individuals ready to share with other, genetically alien individuals? Experiences coming not only from evolutionary psychology studies, but also from ethology provide explanations in this case. Vampire bats are ready to share the blood they have gathered with unrelated individuals to save their mates from certain death by starvation. They do it because the promise of reciprocity tells them to ${ }^{29}$. The social group expects reciprocity from the individuals who receive help. Social species have also been endowed with developed brain modules that serve to identify and punish frauds who do not want to return favours. Studying the specific character of social bonds is very important in management as they find reflection in organisational bonds. Nepotism is a culturally universal mechanism, which may manifest itself in the development of family businesses and in creating family cliques in enterprises and public organisations. Non-kin altruism also occurs in organisations and it is a basis for cooperation between people.

The mechanisms for identifying and punishing social frauds are a foundation of social game in every type of organisation. Thus, proper modelling of organisational processes requires reference to the evolutionary interpretation of social bonds.

\section{Taking risks in a social group}

The tendency to take risks seems a little paradoxical from the perspective of evolution, however only considering the survival of individuals. If we look at it from the point of view of reproduction, evolutionary explanations become coherent. Taking risks, especially by males, is a method of strengthening the reproductive process, particularly for the individuals occupying non-dominating positions. When the alpha male achieves the highest reproductive results, determination of other males to take risks increases. In the case of social species such as humans or apes, this risk does not have to relate only to physical, individual confrontation, it may be related with creating a coalition. In the case of people, it is combined with the possibility of symbolic confrontation, showing advantage in terms that from the social point of view are crucial ${ }^{30}$. Taking risk frequently has a demonstrative aspect, which consists in showing advantage and discouraging to take up confrontation in the case of sexual rivalry or attack in the event of demonstration in front of a predator ${ }^{31}$.

29 R. Axelrod, The Evolution of Cooperation, Basic Books, New York 1984.

30 M. Wilson, M. Daly, Competitiveness, Risk Taking, and Violence: The Young Male Syndrome, in: The Functional Mind. Readings in Evolutionary Psychology, red. D.T. Kenrick, C.L. Luce, Pearson, Boston 2004.

31 J. Dimond, The Third Chimpanzee. The Evolution and the Future of the Human Animal, Harper, New York 1992, pp. 192-215. 
The tendency to take risks in management is one of the most essential features of the dynamic world of organisations. Entrepreneurship is readiness to take the risk of developing a new undertaking. Financial and life-related risk is an inseparable feature accompanying the activities of a manager and an entrepreneur. Ascertainment of the fact how deeply the tendency to take risks is rooted in human nature is very interesting.

\section{Group and organisational communication}

Accumulation of knowledge and output is a condition for enduring change and development of a human society. It is possible on a greater scale owing to the processes of communication. We observe the beginnings of these processes in birds, mammals and particularly apes. The language able to transfer complex and abstract ideas, however, is probably an exclusive domain of the human species and it originates from the connection of social development with brain specialisation. The author of the nativistic concept of language, presently developed by evolutionary psychology $^{32}$, is Noam Chomsky ${ }^{33}$. Human ability to learn a language and the way to use it has probably evolved from a simple system of voice signalling, which later started to serve to transfer emotions and ideas, as well as to describe reality. Next to the verbal communication system, a module of fast non-verbal communication, including, among others, mimics and gestures ${ }^{34}$, developed probably a little earlier. Language, being a sophisticated symbolic system, was also a positive stimulus for the integration of a social group and for a change and creation of more developed groups and societies. Due to the absence of material traces, it is very difficult to analyse the evolutionary influence of language development on the human species. However, it might have been one of the causes of the great shift, which led to shaping the homo sapiens species as it looks today ${ }^{35}$. Language is a key binding agent of every social group or organisation and a basis for creating a culture. It is often perceived as obvious, which resulted in the fact that its role has only been noticed in relation to comparative intercultural studies ${ }^{36}$.

32 S. Pinker, Language as an Adaptation on the Cognitive Niche, in: The Functional Mind. Readings in Evolutionary Psychology, red. D.T. Kenrick, C.L. Luce, Pearson, Boston 2004.

33 N. Chomsky, Language and Thought, Mayer Bell, Wakefield, Rhode Island, London 1993.

34 P. Ekman, W.V. Friesen, Constants across Cultures in the Face and Emotion, in: The Functional Mind. Readings in Evolutionary Psychology, red. D.T. Kenrick, C.L. Luce, Pearson, Boston 2004.

35 J. Dimond, The Third Chimpanzee. The Evolution and the Future of the Human Animal, Harper, New York 1992, pp. 141-167.

36 G. Hofstede, Culture's Consequences: International Differences in Work-Related Values, Sage, Beverly Hills 1980. 


\section{Masculinity and femininity}

Evolutionary psychology has clearly proved that there are differences between men's and women's cognitive apparatuses and that they result from evolution. Motoric differentiation resulting directly from physiological and hormonal differences is obvious. The most important cognitive differences, however, are related to the skill of spatial orientation ${ }^{37}$, mathematical and linguistic abilities ${ }^{38}$. Emotional differences, on the other hand, refer to distinctions in the popularly accepted "theories of the mind" 39 . In social sciences based on a culturalistic vision, a dogma of political correctness, consisting in eliminating differences between men and women on the basis of biological foundations, reigned ${ }^{40}$. Empirical studies carried out as part of evolutionary psychology, however, allow for observing such distinctions, which, although not fundamental, may be significant for certain aspects of social functioning. That is why management sciences should perhaps consider organisation in terms of mutual influence of relations between genders and analyse the process of directing and organising taking men's and women's preferences into account.

\section{Evolutionary conditioning of the culture of societies and organisations}

Culture may be understood as a symbolic system including a set of beliefs, standards and patterns transmitted socially between individuals. Language is the carrier of culture, and cultural transmission makes it possible to accumulate knowledge and output of a society. With reference to culture, some evolutionary questions remain valid, such as whether culture is an adaptation increasing the chance of individuals' survival, an indirect product of the development of other evolutionary structures (e.g. language and communication) or a side product, which has negative impact on the survival of individuals. Presently, an evolutionary theory of culture has not been formulated. There are some hypotheses, such as memetics ${ }^{41}$, that point to analogies between evolution in a biological sense and change in a cultural meaning ${ }^{42}$, these still are, however, concepts at an early stage of their formulation or testing. Basic studies

37 M. Eals, I. Silverman, The Hunter-Gatherer Theory of Spatial Sex Differences: Proximate Factors Mediating the Female Advantage in Recall of Object Arrays, in: The Functional Mind. Readings in Evolutionary Psychology, red. D.T. Kenrick, C.L. Luce, Pearson, Boston 2004.

38 Kimura D., Płeć i poznanie, PIW, Warszawa 2006.

39 M.G. Haselton, D.M. Buss, Error Management Theory: A New Perspective on Biases in Cross-Sex Mind Reading, in: The Functional Mind. Readings in Evolutionary Psychology, red. D.T. Kenrick, C.L. Luce, Pearson, Boston 2004.

40 Por. T. Hołówka (ed.), Nikt nie rodzi się kobietą, Czytelnik, Warszawa 1982.

41 R. Dawkins, The Selfish Gene, Oxford University Press, Oxford 1976.

42 R. Allott, Evolution and Culture: The Missing Link, in: The Darwinian Heritage and Sociobiology, red. J.G. Dennen, D. Smillie, D.R. Wilson, Praeger, Westport, CT 1999, pp. 67-70. 
carried out on the basis of neuroscience give hope for finding fundamental brain mechanisms that reflect cognitive processes related to the creation of the phenomenon of culture ${ }^{43}$. Michael Tomasello is convinced that human cognitive apparatus is based on a cultural foundation, which makes it possible to accumulate the output, identify with the community, learn, communicate and develop abstract thinking and creativity ${ }^{44}$. Culture is a key notion in social sciences. Sociology, cultural anthropology, social psychology, history and other disciplines consider culture as a core concept. In management sciences there is a key notion of organisational culture, which derives from understanding culture in humanistic sciences. The explanation of biological mechanisms of cultural transmission will probably be a ground-breaking achievement for all disciplines that refer to its theory, and it will undoubtedly contribute to better understanding of the complexity of the organisational culture and related notions, such as organisation's identity or image.

Evolutionary explanations of social processes are not merely hypotheses. They are the theories verified by empirical research that remain compliant with the basic assumptions of the neoevolutionary paradigm. The methodology applied in studying evolutionary psychology, sociobiology and neuroscience refers to both traditional tools of social sciences (survey studies, comparative studies, observations and qualitative techniques), and brain study techniques (e.g. PET) and behaviour of animals, which were earlier applied only in natural science.

\section{Examples of applying evolutionary inspirations to management}

"Human nature" having its evolutionary roots growing from the past of the human species and other species that had preceded it, by activities of man finds reflection in numerous management domains. It concerns HR management, organisational behaviours, organisation sociology and theory of organisation or marketing.

The theory of organisation based on evolutionary assumptions takes the structure of needs and the evolutionary construction of man's cognitive and emotional apparatus into account. It means, among others, that in all motives of action we must look for a hidden agenda in the form of strengthening individual's position and physical or symbolic reproduction. Contemporary society, group and organisation are perceived through the perspective of a million years of experience of anthropoids in gathering and hunting groups. Thus, the needs of people, their phobias, representations, 2006.

43 B.E. Wexler, Neurobiology, Ideology and Social Change, A Bradford Book, The MIT Press, Cambridge

44 M. Tomasello, Kulturowe źródła ludzkiego poznania, PIW, Warszawa 2002, pp. 18-19. 
stereotypes, metaphors and emotions are rooted in that space and time. Although contemporary people use high technologies and the most abstract knowledge, in the emotional sense they remain troglodytes.

The search for evolutionary inspirations for the development of organisational structures refers to the concepts of power and hierarchy. Paths of spontaneous development of organising processes and self-organisation, as well as the crystallisation of power and authority, may be searched for. At the present stage of cognition, the influence of evolutionary conditioning on the establishment of formalised structures seems difficult to be clearly specified. Power and authority, however, are fundamental actions deeply rooted in the human mind and founded on a biological basis.

The strategy of organisation, however, refers to the concept of planning and game. Together with the development of mind abilities, the human species has obtained the possibility to plan the future and computative skills to play multi-variant games that allow the calculation of profits and selection of optimum solutions. Strategies chosen collectively or by leaders influence the entire community, which proves that there are some profound, often unconscious decision-making mechanisms. One of the poorly studied mechanisms that plays a great role in management is making a decision according to one's intuition. Antonio Damasio claims that the symptoms of intuitive decisions are the somatic and emotional reactions of an organism, e.g. a concern related to an excessively risky variant is manifested with fear and stomach cramps $^{45}$. Many authors suggest that decisions are mainly made in an unconscious manner, in the blink of an eye, while our conscious interpretations remain merely post factum rationalisations ${ }^{46}$.

The processes of directing are related both to fighting for domination in a group and to abilities to build coalitions and communicate. Seeking psychological and social profiles of alpha individuals, leaders and coalition leaders, as well as describing the dynamics of the interplay between these individuals and the group, is an interesting challenge. Yet, leadership is a dynamic process, related to the team profile and to the nature of the task. On the other hand, however, it is immanently connected with the leader's characteristic features and his relations with the group. The difference between "male" and "female" management styles may result from differences in the structure of the cognitive and emotional apparatus.

HR management refers to the theories of recruitment, motivation and development, which are based on an overrationalised vision of human nature, which is close to the assumptions of a homo oeconomicus. Yet, as brain studies prove, numerous de-

45 A.R. Damasio, Descartes' Error: Emotion, Reason, and the Human Brain, Putnam, New York 1994.

46 Por. K.E. Weick, Managing the Unexpected, Jossey-Bass, San Francisco 2001; M. Gladwell, Blink: The Power of Thinking of Thinking Without Thinking, Time Warner Book Group, New York 2005. 
cisive processes remain outside conscious control, which requires a revision of the HR management theory ${ }^{47}$.

We may point to several assumptions of formulating a marketing theory that respects the discoveries of neoevolutionism. Firstly, all human behaviours have evolutionary origin. They may result either directly from evolutionary construction, such as the need to eat highly caloric food or from sexual competition, or they have been subject to certain modifications, e.g. the need to compete and fight has presently assumed a symbolic form instead of a physical one. Secondly, evolutionary explanations refer to the functionality of human behaviours in a primitive community. Today, the same behaviours may have impractical features. For instance, man's inclination to drink alcohol may be a consequence of searching for ripe fruit with the highest content of sugar and ethanol, in which the fermentation process has begun. Thirdly, among the features influencing human behaviours there are adaptations, but also indirect products, or even accidental effects. Adaptations evolved and favoured survival or reproduction in natural conditions. Indirect products were created on the occasion of functional solutions, but they neither bring forward any solutions favouring survival nor are functional (e.g. a navel). Accidental effects are not functional either, they may have a varying, individual character (e.g. eye colour) ${ }^{48}$. The analysis of studies based on a neoevolutionary paradigm from the point of view of its application to marketing leads to interesting results. First of all, it proves that under extremely complex patterns of human behaviours there is a coherent evolutionary concept, which may explain it. Furthermore, it restricts the problem of cultural relativism that makes it impossible to use similar ideas in various communities, pointing to universal values that have evolutionary roots, such as needs and emotions. The explanation of a number of human behaviours exceeding the homo oeconomicus perspective is an interesting consequence of studies conducted as part of the neoevolutionary approach. Seemingly irrational and illogical actions often comply with the structure of needs and with the specific nature of human nature's evolutionary construction ${ }^{49}$. Marketing as a discipline based on sciences dealing with human behaviour, at the same time strongly connected with the market practice, have gradually discovered heuristics which allows effective impact on man.

Many evolutionary explanations also make it possible to better understand the psychological and social foundations of the effect of money (e.g. risk factors, speculating on the stock exchange, economy, wastefulness etc.). Darwinism, supported by reliable studies of the brain, even allows to obtain knowledge that is useful in strategic

47 S.M. Colarelli, No Best Way. An Evolutionary Perspective on Human Resource Management, Praeger, London 2003.

48 D.M. Buss, Evolutionary Psychology. The New Science of the Mind, Pearson, Boston 2008, pp. 39-40.

49 Por. R.H. Frank, The Economic Naturalist. In Search of Explanations for Everyday Enigmas, Perseus Books, New York 2007, pp. 163-182. 
management. Planning, sense of time and tendency to take risks have their biological foundations in man's cognitive and emotional apparatus and they served to increase the chance of survival in a primitive society.

Various problems and subdisciplines have emerged among the above mentioned examples. It seems that evolutionary thinking may be an interesting and universal interpretative basis that allows more profound understanding of behaviours of individuals and activities of social groups and organisations.

\section{Conclusion}

Table 1 presents an attempt to interpret relations between man's evolutionary nature and a social group's nature that result from it, which leads to the characteristics of the organising process. It does not include all elements of evolutionary psychology theory because studies of certain aspects of human behaviour in the context of management are very limited.

Evolutionism opens new horizons to sciences. It is possible to re-interpret a number of phenomena of organisation and management from the perspective of a description of social human nature rooted in the evolutionary process:

1. Theory of organisation should take the influence of human and evolutionary characteristics of a social group on the management process into account.

2. Organisation is also a coalition of cooperating individuals connected with social bonds of evolutionary nature.

3. Important motives of organising include: willing to reinforce power and individual influences, improving the status and pursuit of symbolic reproduction.

4. Strategic, structural and cultural organisational processes have their roots in evolutionary concepts.

5. Many subdisciplines, such as HR management, marketing, strategic management or even finance may use the results of studies of evolutionary sources of human behaviour with the purpose of developing models of man's economic and organisational activities. 
Table 1. Nature of an individual and a social group versus the characteristics of the organising process in the light of the neoevolutionary paradigm

\begin{tabular}{|c|c|c|}
\hline $\begin{array}{c}\text { Nature } \\
\text { of an individual }\end{array}$ & $\begin{array}{l}\text { Nature } \\
\text { of a social group }\end{array}$ & Organising process \\
\hline $\begin{array}{l}\text { Social nature of } \\
\text { an individual }\end{array}$ & $\begin{array}{l}\text { Spontaneous emergence of a social } \\
\text { group: communication, power, struc- } \\
\text { ture and bonds }\end{array}$ & $\begin{array}{l}\text { Spontaneous emergence of organising pro- } \\
\text { cesses: leadership, plan, motivation }\end{array}$ \\
\hline Kin altruism & $\begin{array}{l}\text { Strong kin bonds, coalitions between } \\
\text { kin and relatives } \\
\text { Parental investment }\end{array}$ & $\begin{array}{l}\text { Culturally universal influence of nepotism on } \\
\text { organising }\end{array}$ \\
\hline $\begin{array}{l}\text { Mutual coopera- } \\
\text { tion with the un- } \\
\text { related }\end{array}$ & $\begin{array}{l}\text { Alliances and coalitions between the } \\
\text { unrelated with the purpose of achiev- } \\
\text { ing a joint advantage }\end{array}$ & $\begin{array}{l}\text { Creation of an organisation understood } \\
\text { as a purposeful social group aiming at the } \\
\text { completion of a joint project. }\end{array}$ \\
\hline $\begin{array}{l}\text { Natural sources } \\
\text { of the structure } \\
\text { of power and hi- } \\
\text { erarchy }\end{array}$ & $\begin{array}{l}\text { Spontaneous emergence of power, } \\
\text { structure and hierarchy putting the so- } \\
\text { cial group in order }\end{array}$ & $\begin{array}{l}\text { Informal structure, followed by formal struc- } \\
\text { ture and hierarchy, are intuitively understood } \\
\text { and accepted as natural order. }\end{array}$ \\
\hline $\begin{array}{l}\text { Pursuit of domi- } \\
\text { nation, fight and } \\
\text { conflict }\end{array}$ & $\begin{array}{l}\text { Fight for domination and conflict are } \\
\text { immanent features of a social group } \\
\text { and intergroup relations (e.g. war) }\end{array}$ & $\begin{array}{l}\text { Pursuit of domination, fight and conflict are } \\
\text { a source of intraorganisational competition } \\
\text { and they drive rivalry between organisations. }\end{array}$ \\
\hline Sexual selection & $\begin{array}{l}\text { Drive to reproduction and striving for } \\
\text { the selection of sexual partners with } \\
\text { the highest possible evolutionary value }\end{array}$ & $\begin{array}{l}\text { Hidden meaning of sexual motivations in } \\
\text { competition processes between individuals } \\
\text { in organisations }\end{array}$ \\
\hline $\begin{array}{l}\text { Leadership, ex- } \\
\text { ercise of power }\end{array}$ & $\begin{array}{l}\text { leader or coalitions of leaders } \\
\text { nerge naturally and pursue consoli- } \\
\text { ation of power }\end{array}$ & $\begin{array}{l}\text { are recognised, gain or lose au- } \\
\text { nd legitimacy, and can make deci- } \\
\text { behalf of the group }\end{array}$ \\
\hline $\begin{array}{l}\text { Learning, } \\
\text { innovation, re- } \\
\text { sourcefulness, } \\
\text { creativity }\end{array}$ & $\begin{array}{l}\text { Solving open problems in an unstable } \\
\text { environment (also the social one) re- } \\
\text { quires creativity and is an advantage } \\
\text { in a group }\end{array}$ & $\begin{array}{l}\text { Entrepreneurship, which combines intellec- } \\
\text { tual potential with organisational attitude } \\
\text { and activity, is a manifestation of creativity } \\
\text { and innovation in management }\end{array}$ \\
\hline $\begin{array}{l}\text { Cognitive pro- } \\
\text { cesses - se- } \\
\text { lective memory } \\
\text { (people, faces, } \\
\text { narrations) }\end{array}$ & $\begin{array}{l}\text { Adaptation to act and organise inside } \\
\text { a small group, in which knowing peo- } \\
\text { ple is of personal character }\end{array}$ & $\begin{array}{l}\text { The effects are: limited management range, } \\
\text { greater entrepreneurship of small groups } \\
\text { and bureaucratic tendencies of larger or- } \\
\text { ganisations }\end{array}$ \\
\hline $\begin{array}{l}\text { Planning the fu- } \\
\text { ture }\end{array}$ & $\begin{array}{l}\text { Social decisions and strategies for the } \\
\text { survival of the group taking the future } \\
\text { into account }\end{array}$ & $\begin{array}{l}\text { The process of formal and informal planning } \\
\text { of group action variants and monitoring their } \\
\text { implementation }\end{array}$ \\
\hline $\begin{array}{l}\text { Group and or- } \\
\text { ganisational } \\
\text { communication }\end{array}$ & $\begin{array}{l}\text { Language community results in: } \\
\text { strengthening bonds and the possibil- } \\
\text { ity to accumulate and transfer group } \\
\text { knowledge }\end{array}$ & $\begin{array}{l}\text { Communication is a key aspect of organis- } \\
\text { ing, leadership and management, both from } \\
\text { the point of view of organisational identity } \\
\text { and process coordination }\end{array}$ \\
\hline $\begin{array}{l}\text { Evolutionary } \\
\text { conditioning of } \\
\text { culture }\end{array}$ & $\begin{array}{l}\text { Spontaneous emergence of culture on } \\
\text { the basis of a communicational com- } \\
\text { munity in a group }\end{array}$ & $\begin{array}{l}\text { Spontaneous emergence of organisational } \\
\text { cultures and cultural patterns of manage- } \\
\text { ment }\end{array}$ \\
\hline
\end{tabular}

Source: own study. 
Neoevolutionism must not be treated as a solution to all cognitive problems of social sciences. On the contrary, we are unable to answer a large number of questions arising as a result of applying the evolutionary paradigm to human behaviours. For instance, why aren't people slaves of genetic reproduction in their behaviours? An attempt to combine study results and interpretations taken from social disciplines with the evolutionary way of thinking and study results from natural sciences, such as biology, genetics, ethology, information technologies and neuroscience, seems to be an epistemological solution. I hope that such a combination will allow to solve even the most complex cognitive problems concerning man's world, which so far have been an exclusive domain of social sciences and the humanities.

Universality is the basic value of the evolutionary paradigm, newly discovered in social sciences, because it may be a basis for describing man's behaviours from different points of view, irrespective of affiliation to different disciplinary discourses. Evolutionary inspirations are of interdisciplinary nature. Universality and interdisciplinarity do not mean the will to eliminate detailed disciplines from scientific discourse. Evolutionary paradigm may serve as a basis for deliberations on many detailed problems and it seems that there is no point in assuming a reductionist position that limits the description of human behaviours only to biological interpretations.

Another value of the evolutionary paradigm is the empirical methodology of research, allowing the diagnosis and description of the state, as well as the construction of models and forecasting changes. Applying recent results to studies of brain and behaviours, sophisticated mathematical apparatus and creative association of interpretations taken from various sciences make it possible to develop research that so far has been an element of indirect studies to a scale that was unknown in social sciences. Thus it seems that management, similarly to other social sciences, has a chance to better understand human nature, which we will find in a number of fields of interest in our discipline. Processes of management, leadership and execution of power, communication, conflict and cooperation, as well as relations and differences between genders cannot be explained without a reference to evolutionism. A new paradigm, which can be defined as neevolutionism, has accumulated a number of studies and theories creating a coherent image of man in an environment from the point of view of social sciences.

\section{Bibliography}

Advances in Behavioral Economics, red. C.F. Camerer, G. Loewenstein, M. Rabin, Princeton University Press, Princeton NJ 2001.

Allott R., Evolution and Culture: The Missing Link, in: The Darwinian Heritage and Sociobiology, red. J.G. Dennen, D. Smillie, D.R. Wilson, Praeger, Westport, CT 1999, pp. 67-70. 
Axelrod R., The Evolution of Cooperation, Basic Books, New York 1984.

Barkow J., Cosmides L., Tooby J., The adapted mind: Evolutionary psychology and the generation of culture, Oxford University Press, Oxford 1992.

Barrett H.C., Adaptations to Predators and Prey, in: The Handbook of Evolutionary Psychology, red. D.M. Buss, Wiley, New York 2005, pp. 200-223.

Barrett L., Dunbar R., Lycett J., Human Evolutionary Psychology, Palgrave Macmillan, New York 2002, pp. 22-44.

Bateson W., Mendel's Principles of Heredity, a Defense, First Edition, Cambridge University Press, London 1902. On-line Facsimile Edition: Electronic Scholarly Publishing, prepared by Robert Robbins.

Buss D.M., Evolutionary Psychology. The New Science of the Mind, Pearson, Boston 2008.

Campbell A., A Few Good Men: Evolutionary Psychology and Female Adolescent Aggression, in: The Functional Mind. Readings in Evolutionary Psychology, red. D.T. Kenrick, C.L. Luce, Pearson, Boston 2004.

Chomsky N., Language and Thought, Mayer Bell, Wakefield, Rhode Island, London 1993.

Colarelli S.M., No Best Way. An Evolutionary Perspective on Human Resource Management, Praeger, London 2003.

Combs B., Slovic P., Newspaper Coverage of Causes of Death, "Journalism Quarterly" 1979, no. 56 , pp. $837-843$.

Damasio A.R., Descartes' Error: Emotion, Reason, and the Human Brain, Putnam, New York 1994.

Dawkins R., The Selfish Gene, Oxford University Press, Oxford 1976.

Dimond J., The Third Chimpanzee. The Evolution and the Future of the Human Animal, Harper, New York 1992.

Eals M., Silverman I., The Hunter-Gatherer Theory of Spatial Sex Differences: Proximate Factors Mediating the Female Advantage in Recall of Object Arrays, in: The Functional Mind. Readings in Evolutionary Psychology, red. D.T. Kenrick, C.L. Luce, Pearson, Boston 2004.

Ekman P., Friesen W.V., Constants across Cultures in the Face and Emotion, in: The Functional Mind. Readings in Evolutionary Psychology, red. D.T. Kenrick, C.L. Luce, Pearson, Boston 2004.

Elworthy C., Homo Biologicus. An Evolutionary Model for the Human Sciences, Internet, 1993, downloaded in 2007.

Fodor J.A., The Modularity of Mind: An Essay in Faculty Psychology, The MIT Press, 1983.

Frank R.H., The Economic Naturalist. In Search of Explanations for Everyday Enigmas, Perseus Books, New York 2007. 
Frischhoff B., For Those Condemned to Study Past: Heuristics and Biases In Hindsight, in: Judgment Under Uncertainty: Heuristics and Biases, red. D. Kahneman, P. Slovic, A. Tversky, Cambridge University Press, New York 1982, pp. 335-350.

Gilovich T., Griffin D., Kahneman D., Heuristics and Biases: The Psychology of Intuitive Judgment, Cambridge University Press, New York 2002.

Gladwell M., Blink. The Power of Thinking Without Thinking, Time Warner Book Group, New York 2005.

Gould S.J., Lewontin R., The spandrels of San Marco and the Panglossion paradigm: a critique of the adaptationist programme. Proc R Soc Lond B 205, 1979, pp. 581-598.

Hamilton W.D., The Genetical Evolution of Socila Behaviour, „Journal of Theoretical Biology” 1964, no. 7, pp. 1-52.

Haselton M.G., Buss D.M., Error Management Theory: A New Perspective on Biases in CrossSex Mind Reading, in: The Functional Mind. Readings in Evolutionary Psychology, red. D.T. Kenrick, C.L. Luce, Pearson, Boston 2004.

Hofstede G., Culture's Consequences: International Differences in Work-Related Values, Sage, Beverly Hills 1980.

Kimura D., Płeć i poznanie, PIW, Warszawa 2006.

Miller G., The mating mind: how sexual choice shaped the evolution of human nature, Heineman, London 2000.

Nickerson R., Confirmation Bias: A Ubiquitous Phenomenon In Many Guises, „Review of General Psychology" 1998, no. 2, pp. 175-220.

Nikt nie rodzi się kobietą, red. T. Hołówka, Czytelnik, Warszawa 1982.

Pinker S., Language as an Adaptation on the Cognitive Niche, in: The Functional Mind. Readings in Evolutionary Psychology, red. D.T. Kenrick, C.L. Luce, Pearson, Boston 2004.

Seligman M.E.P., Hager J.L., Biological Boundaries of Learning: The Sauce-Bernaise Syndrome, in: The Functional Mind. Readings in Evolutionary Psychology, red. D.T. Kenrick, C.L. Luce, Pearson, Boston 2004.

Spencer H., Principles of Biology 1864, vol. 1, p. 444, after: M.E. Stucke, Better Competition Advocacy, http://works.bepress.com/cgi/viewcontent.cgi?article=1000\&context $=$ maurice_stucke.

Sułkowski Ł., Paradygmat neoewolucyjny w naukach o zarządzaniu, „Przegląd organizacji” 2009, no. 3 .

Sułkowski Ł., W cieniu Darwina - inspiracje ewolucjonistyczne w zarządzaniu, „Współczesne Zarządzanie" 2008, no. 4.

Thaler R., Kahneman D., Knetsch J., Experimental Tests of the Endowment Effect and the Coase Theorem, "Journal of Political Economy" 1990.

Tomasello M., Kulturowe źródła ludzkiego poznania, PIW, Warszawa 2002, pp. 18-19. 
Tooby J., Cosmides L., Toward Mapping the Evolved Functional Organization of Mind and Brain, in: The New Cognitive Neuroscience, M. Gazzaniga (red.), MIT Press, Cambridge 2000, pp. 1167-1178.

Trivers R.L., The Evolution of Reciprocal Altruism, „Quarterly Review of Biology” 1971, no. 46, pp. 35-57.

Tversky A., Kahneman D., Availability: A Heuristics for Judging Frequency and Probability, in: Judgment Under Uncertainty: Heuristics and Biases, red. D. Kahneman, P. Slovic, A. Tversky, Cambridge University Press, New York 1982.

Weick K.E., Managing the Unexpected, Jossey-Bass, San Francisco 2001.

Wexler B.E., Neurobiology, Ideology and Social Change, A Bradford Book, The MIT Press, Cambridge 2006.

Wilson D.S., Wilson E.O., Rethinking the Theoretical Foundations of Sociobiology, "The Quarterly Review of Biology" 2007, 82 (4), pp. 327-348.

Wilson E.O., Socjobiologia, Zysk i S-ka, Poznań 2001.

Wilson M., Daly M., Competitiveness, Risk Taking, and Violence: The Young Male Syndrome, in: The Functional Mind. Readings in Evolutionary Psychology, red. D.T. Kenrick, C.L. Luce, Pearson, Boston 2004.

\section{Abstract}

The purpose of the article is to outline the perspective of the influence of contemporary evolution concept on social sciences, management in particular. It covers searching for sources of the processes of organisation and management in the biological and social specificity of the homo sapiens species.

KEY WORDS: EVOLUTIONARY MANAGEMENT, NEOEVOLUTIONISM, EVOLUTIONARY PSYCHOLOGY, EVOLUTIONARY ECONOMICS 